\title{
Winstneming bij inbreng van activa in een joint venture
}

Drs. E. Eeftink

\section{Inleiding}

In het bedrijfsleven zijn samenwerkingsvormen en allianties aan de orde van de dag. De doelen van samenwerking kunnen velerlei zijn, bijvoorbeeld het ontwikkelen van nieuwe activiteiten, het combineren van technologieën teneinde deze naar de markt te brengen, het behalen van schaalvoordelen, het betreden van nieuwe markten, of juist het gedeeltelijk uittreden uit bepaalde markten. In veel gevallen wordt een samenwerking gerealiseerd in de vorm van een joint venture.

Een joint venture kan worden omschreven als een economische activiteit, al dan niet in de vorm van een vennootschap of rechtspersoon, waarin door een beperkt aantal deelnemers een zodanige actieve gezamenlijke invloed kan worden uitgeoefend dat iedere deelnemer afzonderlijk geen beleidsbeslissingen kan nemen of afdwingen'. Kenmerkend voor een joint venture is derhalve het bestaan van 'joint control'2. Bij oprichting van een joint venture brengen de deelnemers veelal eigen activiteiten en activa in, in ruil voor een belang in de joint venture.

Vanuit de optiek van de deelnemers in een joint venture kunnen als belangrijkste verslaggevingsaspecten worden aangemerkt:

-- de wijze van verwerking van het belang in de joint venture door de deelnemer: ofwel volgens de vermogensmutatiemethode, ofwel proportionele consolidatie;

winstneming op aankoop- en verkooptransacties met de joint venture, waaronder de wijze van verwerking van inbreng van eigen activa in de joint venture.

In dit artikel wordt nader ingegaan op het tweede aspect, met name de situatie waarin bij de oprichting van een joint venture door een of meerdere deelnemers activa en passiva ${ }^{3}$ worden ingebracht. Daarbij komt de vraag op of de deelnemer die activa/passiva inbrengt in de joint venture winst kan nemen op zijn inbreng. In wezen betreft dit de vraag of de inbrengtransactie tegen fair value moet worden verwerkt, waarbij winst of verlies wordt genomen, of dat de historische boekwaarden van de ingebrachte activa worden doorgeschoven als waardering van het belang in de joint venture. Deze vraag kan vervolgens in tweeën worden gesplitst.

1 Onder welke omstandigheden kan de deelnemer het verkregen belang in de joint venture als een gerealiseerde opbrengst beschouwen die tegen fair value wordt verwerkt? Met andere woorden, welke criteria voor verwerking zijn relevant?

2 Indien aan de criteria voor verwerking is voldaan, hoe dient dan bij de bepaling van de omvang van de winst rekening te worden gehouden met het doorlopende belang dat de deelnemer houdt in de activa die in de joint venture zijn ingebracht?

Dat de eerste vraag actueel is, wordt onderstreept door recente publicaties van internationale regelgevers op het gebied van de externe verslaggeving. Zo heeft de Standing Interpretations

Drs. E. Eeftink RA is directeur bij KPMG Accountants N.V. en studeerde bedrijfseconomie en Accountancy aan de Vrije Universiteit Amsterdam. Hij is tevens lid van de Raad voor de Jaarverslaggeving en hoofddocent Externe Berichtgeving bij de Postdoctorale Controllersopleiding van de Vrije Universiteit Amsterdam. 
Committee (SIC) van het IASC in december 1998 SIC 13, Jointly Controlled Entities - Non Monetary Contributions by Ventureres, gepubliceerd. De SIC is een commissie van het IASC die tot 'Consensus Interpretations' komt van bestaande IAS-standaarden met betrekking tot actuele verslaggevingsvraagstukken. Daarnaast heeft de Amerikaanse SEC recentelijk een brief geschreven aan de Emerging Issues Task Force (EITF) van de FASB waarin wordt verzocht ${ }^{+}$om een project te starten dat ingaat op winstneming bij diverse typen 'nonmonetary exchanges'.

De tweede vraag (hoe wordt de omvang van de winst bepaald) komt slechts aan de orde indien de eerste vraag tot de uitkomst leidt dat winst wordt verantwoord. Omtrent deze tweede vraag is sinds december 1997 een (ontwerp) stellige uitspraak opgenomen in de RJ Richtlijnen, die overigens is gebaseerd op IAS 31, Financial Reporting of Interests in Joint Ventures'. De bepalingen komen erop neer dat een deelnemer in een joint venture bij inbreng of verkoop van activa aan een joint venture op proportionele basis winst vaststelt, dat wil zeggen dat deel van de winst dat correspondeert met het relatieve belang dat andere deelnemers in de joint venture houden. Het deel van de winst dat correspondeert met het eigen belang in de joint venture dient derhalve uit de winstberekening te worden geëlimineerd. Proportionele winstbepaling dient volgens de RJ overigens zowel in de enkelvoudige als in de geconsolideerde jaarrekening plaats te vinden.

Hoewel dit artikel primair ingaat op winstneming bij inbreng van activa in een joint venture, is een groot deel van de inhoud eveneens van toepassing indien eigen activa worden ingebracht in ruil voor een belang in een deelneming. Mogelijke verschillen in de externe verslaggeving hangen samen met de omstandigheid dat er bij een deelneming geen sprake is van 'joint control', maar van een geringere mate van invloed op het zakelijke en financiële beleid ("invloed van betekenis'). Ook op dit terrein heeft de SIC onlangs 'consensus' bereikt (SIC 3, Elimination of Unrealised Profits and Losses on Transactions with Associates).

De opbouw van het artikel is als volgt. In paragraaf 3 wordt ingegaan op de overwegingen die van belang zijn voor het al dan niet verwerken van een inbreng van activa tegen fair value (het verwerken als opbrengst). Daarbij wordt ingegaan op de criteria die zijn opgenomen in SIC 13 en in de Amerikaanse regelgeving. Paragraaf 4 gaat vervolgens nader in op de mogelijke eliminatie van (een deel) van deze opbrengst op grond van het doorlopende economische belang dat de deelnemer in de activa behoudt. Paragraaf 5 behandelt enkele bijzonderheden met betrekking tot de inbreng van goodwill. Een samenvatting en conclusies zijn opgenomen in paragraaf 6 .

\section{Verschijningsvormen van joint ventures en samenwerkingsverbanden}

Joint ventures kunnen al dan niet de vorm hebben van een vennootschap of rechtspersoon. Bij een samenwerking tussen partijen die niet de vorm heeft van een vennootschap of rechtspersoon kunnen activa ter beschikking worden gesteld waarover de inbrengende partij zelf de volledige zeggenschap behoudt. In een dergelijke verschijningsvorm zal van winstneming in het algemeen geen sprake kunnen zijn. Dit type joint venture blijft in dit artikel verder buiten beschouwing.

Joint ventures en samenwerkingsverbanden kunnen via diverse structuren totstandkomen. Hierna zijn ter illustratie enkele voorbeelden opgenomen.

Onderneming A heeft een 100\%-dochtermaatschappij $B$ en onderneming $C$ heeft een $100 \%$ dochtermaatschappij $D$.

$B$ en $D$ zijn beide actief in dezelfde bedrijfstak.
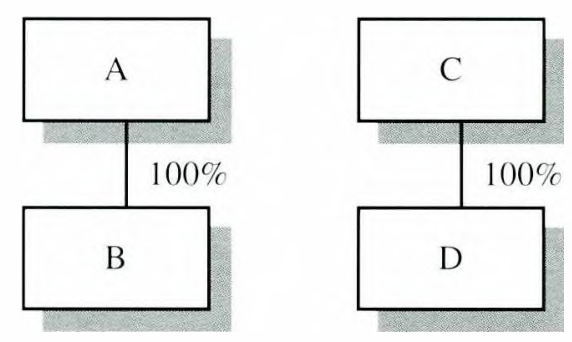

Figun 1: Voorbeeld

Onderneming $\mathrm{A}$ en onderneming $\mathrm{C}$ besluiten een joint venture op te richten waarin hun activiteiten $\mathrm{B}$ en $\mathrm{D}$ worden gecombineerd. Deze joint venture kan bijvoorbeeld volgens de volgende vormen gestalte krijgen. 


\section{Situatie 1}

A brengt $100 \%$ van zijn belang in B in in D. waartegenover $\mathrm{D}$ een $50 \%$-aandelenbelang toekent aan A. De structuur is daarmee als volgt geworden:

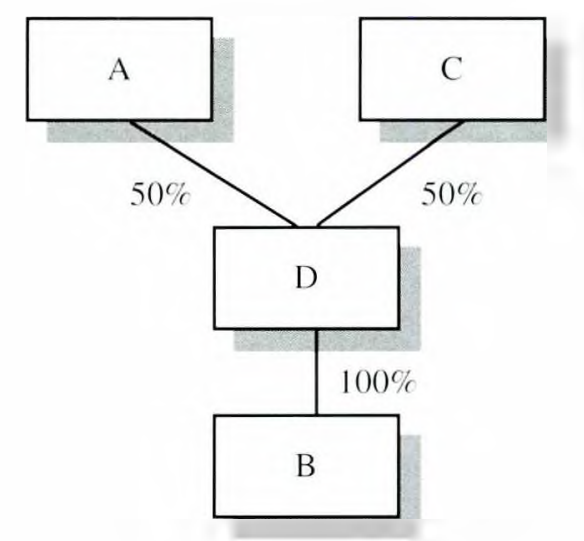

\section{Figun! ?: Situntie I}

Ook het ongekeerde is uiteraard mogelijk. waarbij $\mathrm{B}$ een $100 \%$-belang verwerft in D en B aandelen uitgeeft aan $C$.

\section{Situratic?}

Onderneming A en $C$ richten samen Newco op en brengen hun dochtermaatschappijen $B$ en $D$ in. elk in ruil roor een $50 \%$-belang in Newco.

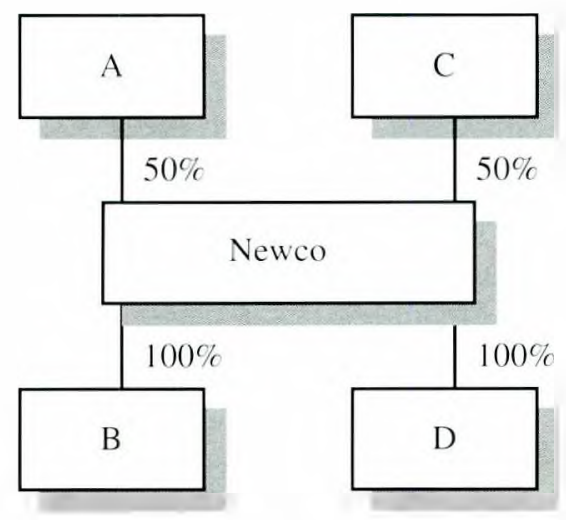

Figmu 3: Situcatic?

Uiteraard zijn eveneens varianten denkbaar waarbij één der partijen een dominante positie inneemt en het samenwerkingsterband daardoor niet als een joint venture valt te kwalificeren. Dit is bijvoorbeeld het geval indien één partij een meerderheidsbelang verwerft en daaraan beslissende zeggenschapsrechten kan ontlenen.

Indien onderneming A een zodanig dominante positie verwerft dat B/D kan worden aangemerkt als een groepsmaatschappij. gaat vanuit de optiek van A "control" over B niet verloren en zullen de financiële gegevens van B via consolidatie begrepen blijven in de geconsolideerde jaarrekening van de A-groep. Met betrekking tot consolidatie gaal zowel de Nederlandse als internationale regelgeving uit van volledige eliminatie van de effecten van transacties tussen geconsolideerde maatschappijen, ook indien het groepsbelang in één of beide betrokken maatschappijen kleiner is dan $100 \%$. Hieruit valt af te leiden dat winstneming op de inbreng van $B$ vanuit de optiek van $A$ (en daarmee de problematiek van dit artikel) niet aan de orde is. Wel is er in die situatie sprake van een acquisitie van $\mathrm{D}$ door de $\mathrm{A}$-groep, warop de normale verwerking van een acquisitie van toepassing is. Vanuit C bezien wordt 'control' over de ingebrachte dochtermaatschappij $D$ overgedragen aan een derde partij ( $A$ dan wel Newco). zodat het vaagstuk van winstneming op de inbreng van D wel relevant is.

\section{Criteria voor winstrealisatic}

\subsection{Het realisatiebeginsel en algemene criteria voor de verwerking ran baten}

Voor het onderwerp van winstneming is met name het realisatiebeginsel van belang. In artikel 2:384, lid 2, BW is het realisatiebeginsel ingebed in het voorzichtigheidsbeginsel en als volgt verw'oord: 'Winsten worden slechts opgenomen voorzover zij op balansdatum zijn verwezenlijkt.' De wettelijke bepalingen geven verder geen concrete aanknopingspunten voor de invulling van het realisatiebeginsel.

In het algemeen betreft het realisatiebeginsel de regel die aangeeft op welk moment opbrengsten (in de vorm van ontrangsten van geld of andere activa) in de winst- en verliesrekening worden verwerkt. Volgens het Stramien van de RJ ${ }^{*}$ worden baten in de winst- en verliesrekening verwerkt wanneer een vermeerdering van economisch potentieel. verband houdend met een vermeerdering van een actief of vermindering van vreemd vermogen, heeft plaatsgevonden waarvan de omvang betrouwbaar kan worden vastgesteld". Dit betekent in feite dat de verwerking van baten is gekoppeld aan de verwerking van toenames van activa of vermindering van schulden in de balans. Posten worden volgens de RJ in de balans 
verwerkt indien:

- het waarschijnlijk is dat aan die post verbonden toekomstig economisch voordeel naar of uit de onderneming zal vloeien, en

- de post een kostprijs of waarde heeft waarvan de omvang met betrouwbaarheid kan worden vastgesteld.

Opbrengst wordt in de verslaggeving tot uitdrukking gebracht op het moment dat deze 'verdiend' is door de afronding van het bedrijfsproces dat de opbrengst voortbrengt. Het 'verdienen' van opbrengst heeft dan twee aspecten. In de eerste plaats moet de meest kritieke gebeurtenis van het bedrijfsproces hebben plaatsgevonden, zodat deze als voltooid kan worden aangemerkt. In de tweede plaats moet het realiseren van economisch voordeel waarschijnlijk en meetbaar zijn.

Met betrekking tot activa die worden ingebracht in een joint venture kunnen deze algemene criteria als volgt worden verwoord:

- de aan de activa verbonden risico's en economische voordelen zijn feitelijk aan de joint venture overgedragen ${ }^{10}$; en

- er dient sprake te zijn van een vermeerdering van het economisch potentieel bij de deelnemer in de joint venture waarvan de omvang betrouwbaar kan worden vastgesteld.

Het eerste criterium, overdracht van risico's en economische voordelen, houdt bijvoorbeeld in dat geen opbrengst wordt verwerkt indien de transactie zodanige voorwaarden kent dat de deelnemer in de joint venture in belangrijke mate het economisch risico over de door hem ingebrachte activa blijft lopen. Te denken valt bijvoorbeeld aan bepaalde terugkoopverplichtingen of bepalingen waarbij de uiteindelijke opbrengst voor de inbrenger uitsluitend afhankelijk is van de opbrengsten die de joint venture met de ingebrachte activa weet te genereren'". Ook indien de joint venture niet de vorm van een rechtspersoon of vennootschap heeft en iedere deelnemer volledige zeggenschap houdt over de door hem ter beschikking gestelde activa, zal in het algemeen geen opbrengst worden verwerkt.

Ook deze criteria maken niet meteen duidelijk of een bij inbreng verkregen belang in een joint venture wel als een 'verdiende' opbrengst kan worden aangemerkt. Immers, het rendement van het belang in de joint venture zal mede afhangen van de winstgevendheid en kasstroom van de door de deelnemer zelf ingebrachte activa ${ }^{12}$. Uit de praktijk en uit de internationale regelgeving kan een tweetal benaderingen worden afgeleid:

1 er wordt winst gerealiseerd indien een transactie heeft plaatsgevonden waarbij de als tegenprestatie ontvangen activa ongelijksoortig zijn aan de activa die bij de transactie zijn overgedragen:

2 er wordt alleen dan winst gerealiseerd indien en voorzover de deelnemer in ruil voor zijn inbreng contanten ontvangt of andere monetaire activa die relatief eenvoudig in contanten kumnen worden omgezet.

\subsection{Winstrealisatie tenzij gelijksoortige activa worden ingehracht}

Bij deze benadering wordt een vermeerdering van het economisch potentieel geacht gerealiseerd te zijn indien bij een transactie activa zijn ontvangen die ongelijksoortig zijn aan de activa die bij de transactie zijn overgedragen. Dit is gebaseerd op de gedachte dat niet-monetaire transacties in beginsel op dezelfde wijze worden verwerkt als monetaire transacties, dat wil zeggen tegen fair value $^{13}$. In deze benadering wordt een nietmonetaire transactie alleen dan niet tegen fair value verwerkt indien:

- de transactie niet de afronding van een bedrijfsproces is. maar een ruil inhoudt van gelijksoortige activa; of

- de fair value van de bij de transactie betrokken niet-monetaire activa niet met een redelijke mate van betrouwbaarheid kan worden bepaald.

Uiteraard kan men het begrip 'gelijksoortigheid' van activa in het kader van winstneming op diverse manieren interpreteren. Aangezien 'control' over de ingebrachte activa een wijziging ondergaat, is een belang in een joint venture per definitie ongelijksoortig aan de ingebrachte activa. Sommigen verbinden daaraan de conclusie dat inbreng van activa altijd tegen fair value zou moeten plaatsvinden. Een redelijker opvatting is mijns inziens dat gelijksoortigheid - in het kader van winstneming - wordt beoordeeld binnen de joint venture, op grond van een vergelijking van de activa die door de diverse deelnemers in de joint venture zijn ingebracht. Deze benadering wordt gevolgd door het IASC in SIC 13. Maar 
ook hier kan verschil van inzicht bestaan over de ruimte waarmee 'gelijksoortigheid' zou moeten worden geïnterpreteerd. Uit de centrale paragraaf van SIC 13 valt af te leiden dat het IASC een zeer enge interpretatie van "gelijksoortigheid van activa' hanteert:

'In applying IAS 31.39 to non-monetary contributions to a JCE (jointly controlled entiti) in exchange for an equity interest in the JCE, a venturer should recognise in the income statement for the period the portion of a gain or loss attributable to the equity interests of the other venturers except when:

a the significant risks and rewards of ownership of the contributed non-monetary asset(s) have not been transferred to the JCE;

b the gain or loss on the non-monetary contribution cannot be measured reliably; or

c the non-monetary assets contributed are similar to those contributed by the other venturers. Non-monetary assets are similar to those contributed by other venturers when they have a similar nature, a similar use in the same line of business and a similar fair value. A contribution meets the similarity test only if all of the significant component assets thereof are similar to those contributed by the other venturers."

Met name de laatste zin onder c (A contribution meets ... by the other venturers.) maakt duidelijk dat de SIC gelijksoortigheid van activa zeer eng interpreteert. waardoor ingebrachte activa vrijwel altijd als "ongelijksoortig' moeten worden aangemerkt. Volgens de criteria van de SIC zal winstneming derhalve vrijwel altijd moeten plaatsvinden indien aan de criteria genoenzd onder a en b is voldaan.

\section{Voorbeeld I}

Onderneming A produceert de chemische bulkproducten $\mathrm{t} 1$ en $\mathrm{t} 2$ en verkoopt deze tegen sterk fluctuerende marktprijzen. Onderneming B produceert en verkoopt eveneens de bulkproducten $t 1$ en t2, maar verpakt daarnaast een deel van deze producten in kleinere eenheden, en verkoopt deze aan industriële gebruikers onder langlopende verkoopcontracten. B produceert circa $50 \%$ van het benodigde bulkproduct zelf en koopt de andere helft in bij derden. A en B besluiten een $50-50$ joint venture aan te gaan voor de productie en verkoop van $\mathrm{tl}$ en $\mathrm{t}$ ?, zowel in bulk als in verpakte eenheden. A brengt zijn productieapparaat in met een fair value van 1.100; B brengt zijn verkoopcontracten in met een fair value van 200 , zijn productieapparaat met een fair value van 800 en liggende voorraad met een fair value van 100 .

Volgens de enge interpretatie van SIC 13 zouden de door A en B ingebrachte activa niet als gelijksoortig kunnen worden aangemerkt, aangezien niet alle (significante) afzonderlijke categorieën activa gelijksoortig zijn. In beginsel zouden zowel $\mathrm{A}$ als $\mathrm{B}$ derhalve winst dienen te nemen op hun respectievelijke inbreng in de joint venture.

Naar mijn mening gaat de SIC hiermee vrij ver en zou het de voorkeur hebben gehad om 'gelijksoortigheid' ruim te interpreteren, zodanig dat het karakter van de joint venture als geheel voorop kan staan. Indien een joint venture een voortzetting of uitbreiding van bestaande activiteiten van de deelnemers is in dezelfde bedrijfstak, zoals in dit voorbeeld, zou geen winst moeten worden genomen op de inbreng van activa. Indien de joint venture daarentegen meer het karakter heeft van een gedeeltelijke verkoop van activiteiten aan de andere partner in de joint venture, zoals in voorbeeld 2 (zie hierna), ligt verwerking tegen fair value eerder voor de hand.

\section{Voorbeeld 2}

Onderneming $C$ is producent van de bulkchemicaliën 11 en t2. Onderneming D is producent van de fijnchemicaliën $t 3, t 4$ en $t 5$, waarbij onder meer 22 als grondstof wordt gebruikt. C en D besluiten een 50-50 joint venture aan te gaan voor de productie van $\mathbf{2}$. C brengt zijn t2-productiefaciliteiten in met een fair value van $1.200 \mathrm{en}$ daaraan verbonden bankschulden van 700 . D brengt 500 contanten in. De contanten worden aangewend ter aflossing van bankschulden.

In deze situatie heeft de joint venture voor $\mathrm{C}$ het karakter van een gedeeltelijke verkoop van 12 activiteiten en realiseert $\mathrm{C}$ derhalve opbrengst bij de inbreng van activa en passiva in de joint venture.

\subsection{Alleen winstrealisatie voorzover contanten worden ontrangen}

Bij deze benadering wordt een vermeerdering van het economisch potentieel alleen als gerealiseerd aangemerkt indien en voorzover de deelnemer in ruil voor zijn inbreng contanten ontvangt of andere monetaire activa die relatief eenvoudig in 
contanten kunnen worden omgezet. Dit stoelt op de gedachte dat de afronding van elk bedrijfsproces zich kenmerkt door de ontvangst van monetaire activa, waarvan de omvang en inbaarheid niet afhankelijk is van de verdere bemoeienis met of waardeontwikkeling van de verkochte activa. Indien de deelnemer in een joint venture bij de inbreng van activa geen contanten ontvangt, is het bedrijfsproces kennelijk niet afgerond en is winstneming dus niet aan de orde. Deze benadering valt onder meer af te leiden uit Amerikaanse EITF-uitspraken en SEC-standpunten ${ }^{14}$.

\section{Voorbeeld 3}

Onderneming A bezit productiefaciliteiten met een boekwaarde van 100 en een fair value van 500 . Onderneming B richt een dochtermaatschappij X op en stort daarin 500 contanten. Onderneming A brengt haar productiefaciliteiten in in onderneming $X$ en ontvangt daarvoor een belang van $50 \%$. De balans van onderneming $X$ (opgesteld op basis van fair values) geeft het volgende beeld:

\begin{tabular}{lrrr} 
Productiefaciliteiten & 500 & Aandelen A & 500 \\
Liquide middelen & 500 & Aandelen B & 500 \\
\cline { 2 - 4 } & $\frac{1.000}{1.000}$ & &
\end{tabular}

Onder Amerikaanse regels (EITF 89-7) zou onderneming $A$ geen winst kunnen nemen aangezien zij geen contante opbrengsten realiseert. Indien wordt verondersteld dat de "risks and rewards' met betrekking tot de productiefaciliteiten daadwerkelijk aan X zijn overgedragen, zou A volgens SIC 13 echter winst moeten nemen ter grootte van 200 (50\% van 500-100). Immers, de door beide partners ingebrachte activa zijn duidelijk niet gelijksoortig.

Het ontvangen van contanten of daarmee vergelijkbare liquide activa kan op diverse manieren vorm krijgen. De eenvoudigste vorm is die waarbij de ene deelnemer direct een bijbetaling ontvangt van de andere deelnemer. Ook andere vormen kunnen echter voorkomen, zoals in voorbeeld 4 .

\section{Voorbeeld 4}

Dezelfde gegevens als in voorbeeld 3, maar B brengt geen 500 contanten in maar slechts 50 . Vervolgens trekt $X$ externe financiering aan van 400 met als zekerheid de door A ingebrachte productiefaciliteiten. $X$ keert vervolgens 450 uit aan $\mathrm{A}$. Na deze transacties geeft de balans van $\mathrm{X}$ het volgende beeld:

$\begin{array}{lrlr}\text { Productiefaciliteiten } & 500 & \text { Aandelen A } & 50 \\ \text { Liquide middelen } & 0 & \text { Aandelen B } & 50 \\ & & \text { Externe financiering } & \frac{400}{500}\end{array}$

Volgens Amerikaanse regels (EITF 89-7) zou A in deze situatie een winst dienen te nemen ter grootte van 350 , berekend als volgt:

Fair value van verkochte productiefaciliteit

$(50 \%$ van 500$)$

Af: bockwaarde van verkochte productie-

faciliteit $(50 \%$ van 100$)$

$-50$

Pro rata boeku inst

200

Plus: aansullende winst uit hoofde van

kasontvangsten

$150 *$

Totale boekwinst

350

* Zijnde het saldo van de kasontvangst en de fair value van de verkochte productiefaciliteit (450 minus 250) verminderd met de resterende historische boekwaarde van productiefaciliteit (50). Dit bedrag is zodanig bepaald dat de boekwaarde van de investering in X bij $\mathrm{A}$ op nihil wordt gesteld.

\subsection{Het effect wan een bijbetaling ('boot')}

Een bijzonder aspect betreft de invloed die een bijbetaling heeft op het al dan niet verantwoorden van winst bij de inbreng van activa. Het betreft hier de situatie waarin een onderneming activa inbrengt en in ruil daarvoor niet alleen een belang verwerft in een andere onderneming (een joint venture of deelneming), maar tevens rechtstreeks een bijbetaling ontvangt. In de Amerikaanse regelgeving wordt in dit verband gesproken van 'boot'. In hoofdlijnen zijn twee benaderingen denkbaar met betrekking tot een bijbetaling:

1 Substance. Hoewel er sprake is van een bijbetaling, wordt de inbreng van activa en de ontvangst van de bijbetaling als één geheel bezien, waarbij de transactie op basis van de 'substance' in zijn geheel wordt verwerkt ofwel als een monetaire transactie (winstneming op basis van fair value), ofwel als een ruil van gelijksoortige activa (geen winstneming).

2 Splitsing. Hierbij wordt een ontvangen bijbetaling gezien als de verkoopopbrengst van een 
deel van de ingebrachte activa, zodat winstneming dient plaats te vinden op basis van de ontvangen bijbetaling. De berekening van de winst kan echter op diverse wijzen plaatsvinden (zie voorbeeld 5 ).

De Amerikaanse regelgeving ${ }^{15}$ bevat een combinatie van beide benaderingen. Indien 'boot' een belangrijk bestanddeel is van de transactie, moet de gehele transactie worden behandeld als ware het een monetaire transactie ('substance'). Daarbij vindt verwerking van de gehele transactie plaats tegen fair value met winstneming op de ingebrachte activa. In dit verband wordt 'boot' geacht een belangrijk bestanddeel van de transactie te zijn indien deze ten minste $25 \%$ bedraagt van de totale fair value van de transactie. Indien 'boot' echter minder bedraagt dan $25 \%$ van de fair value van de transactie, vindt winstneming op pro rata basis plaats (splitsing) ${ }^{16}$.

\section{Voorbeeld 5}

Onderneming A en onderneming B komen overeen hun raffinaderijen in land $\mathrm{X}$ te combineren door het vormen van een 50-50 joint venture. De raffinaderij van onderneming $A$ heeft een fair value van 100 (boekwaarde 60), de raffinaderij van onderneming $B$ heeft een fair value van 70 (boekwaarde 65). Ter compensatie van het verschil in fair value doet $B$ een bijbetaling van 15 in contanten aan A.

Indien wordt aangenomen dat hier sprake is van activa die qua aard gelijksoortig zijn en op een gelijksoortige wijze worden aangewend in dezelfde bedrijfstak, wordt de transactie niet op basis van fair values verwerkt en blijft winstneming achterwege. Met betrekking tot de bijbetaling van 15 kunnen diverse uitwerkingen worden gegeven.

Substance. Indien men aanneemt dat de bijbetaling geen belangrijk deel van de transactie uitmaakt, neemt A geen winst en wordt de bijbetaling in mindering gebracht op de boekwaarde van het belang in de joint venture $(60-15=45)$

- Pro rata. Hierbij berekent A een resultaat van 6 (15 minus 15\% van 60), gebaseerd op de gedachte dat de ingebrachte activa voor 15\% als verkocht kunnen worden aangemerkt. Deze berekening is in overeenstemming met de Amerikaanse regels opgenomen in EITF 86-29. Top-sliced. Hierbij berekent A een resultaat van 15 , op grond van de redenering dat winst gerealiseerd is voorzover contanten zijn ontvangen en de fair value van het belang in de joint venture niet beneden de boekwaarde ligt.

Ook in de benadering van het IASC kan een bijbetaling ("boot') een rol spelen bij winstneming. SIC 13 is hier echter zeer summier over en stelt slechts dat: 'If, in addition to receiving an equity interest in the JCE, a venturer receives monetary or non-monetary assets dissimilar to those it contributed, an appropriate portion of gain or loss on the transaction should be recognised by the venturer in the income statement. 'Wat 'an appropriate portion' inhoudt blijft onduidelijk. Echter, door de enge benadering van 'gelijksoortigheid", waarbij onder meer is vereist dat de door de partners ingebrachte activa een "similar fair value' hebben, zal een bijbetaling onder SIC 13 nauwelijks relevant kunnen zijn. Een bijbetaling zal immers vrij snel tot de conclusie moeten leiden dat de door de partners ingebrachte activa geen 'similar fair value' hebben en dat verwerking van de gehele transactie derhalve moet plaatsvinden tegen fair value.

\section{Proportionele winstbepaling: 'joint control' of 'risks and rewards'?}

In deze paragraaf wordt nader ingegaan op de bepaling van de omvang van de winst, indien is komen vast te staan dat de inbreng van activa in een joint venture verwerkt dient te worden tegen fair values (zie paragraaf 3 ). Zoals reeds in de inleiding is vermeld, is in de RJ Richtlijnen een (ontwerp) stellige uitspraak opgenomen die bepaalt dat een deelnemer in een joint venture bij inbreng of verkoop van activa aan een joint venture winst bepaalt op proportionele basis, dat wil zeggen dat deel van de winst dat correspondeert met het relatieve belang dat andere deelnemers in de joint venture houden ${ }^{17}$. Op het eerste gezicht lijkt dit een logische bepaling die geen nadere beschouwing behoeft, aangezien de joint venture een 'related party' is via welke de deelnemer een doorlopend economisch belang houdt in de door hem ingebrachte activa. Noch de RJ noch het IASC (IAS 31 of SIC 13) geven echter aan waarom winst proportioneel moet worden bepaald. Vloeit dit voort uit de omstandigheid dat een deelnemer:

a 'joint control' heeft in de joint venture en daarmee een gedeelde beschikkingsmacht 
behoudt over de ingebrachte activa? In deze visie is proportionele winstneming een element van consolidatie en zou eigenlijk gesproken moet worden van proportionele eliminatie;

b een doorlopend economisch belang behoudt bij de waardeontwikkeling van de ingebrachte activa? In deze visie is proportionele winstbepaling een element van realisatie.

Ik zal mij wagen aan een korte analyse van de mogelijke achtergronden daarvan, aangezien dit weer aanknopingspunten kan bieden voor de reikwijdte van het beginsel van proportionele winstbepaling:

- alleen in de geconsolideerde jaarrekening, of tevens in de enkelvoudige jaarrekening?

- alleen voor transacties met joint ventures, of ook voor transacties met minderheidsdeelnemingen?

\subsection{Proportionele winstbepaling vanwege 'joint control' en consolidatie}

Men zou kunnen argumenteren dat winstbepaling proportioneel dient plaats te vinden vanwege het feit dat de deelnemer via 'joint control' op indirecte wijze toch nog een bepaalde mate van beschikkingsmacht houdt over de door hem ingebrachte activa. In deze benadering is proportionele winstbepaling een onderdeel van de consolidatie, waarbij eliminatie plaatsvindt van dat deel van de winst dat voor het doel van de geconsolideerde jaarrekening als ongerealiseerd moet worden aangemerkt. Het zou dan ook duidelijker zijn om niet te spreken van proportionele winsthepaling, maar van proportionele eliminatie. Indien men deze visie zou aanhangen, kunnen op basis daarvan de volgende opmerkingen worden gemaakt.

1 In beginsel hoeft geen eliminatie plaats te vinden voor het doel van de enkelvoudige jaarrekening, zodat een winst die gerealiseerd is op grond van de criteria in paragraaf 3 volledig genomen kan worden. Dat realisatie voor de enkelvoudige jaarrekening een andere inhoud kan hebben dan voor de geconsolideerde jaarrekening heb ik eerder in dit maandblad onder de aandacht gebracht ${ }^{18}$. Ik heb daarbij betoogd dat, vanwege het eigen doel van de enkelvoudige jaarrekening, het vraagstuk van realisatie onafhankelijk van de groepsrelatie moet worden bezien: transacties tussen groepsmaatschappijen kunnen voor de enkelvoudige jaarrekening tot realisatie van winst leiden, terwijl zij vervolgens in de geconsolideerde jaarrekening dienen te worden geëlimineerd. Indien men van mening is dat proportionele winstbepaling in wezen eliminatie betreft, is hetzelfde van toepassing op transacties met joint ventures.

2 Onder de beginselen van consolidatie worden intercompany-winsten die ontstaan door transacties tussen groepsmaatschappijen volledig geëlimineerd, ook indien het groepsbelang in een of beide groepsmaatschappijen minder bedraagt dan 100\%19. Voor eliminatie is derhalve van belang of er al dan niet sprake is van een groepsmaatschappij (of, in Angelsaksische termen, of er al dan niet sprake is van 'control'). Indien dit het leidende beginsel is, is het spiegelbeeld hiervan dat geen eliminatie dient plaats te vinden van winsten die ontstaan op transacties met niet-groepsmaatschappijen, ongeacht of dit derden zijn of minderheidsdeelnemingen.

\subsection{Proportionele winsthepaling vamvege 'risks and rewards' en realisatie}

Een andere en mijns inziens betere invalshoek is dat proportionele winstbepaling plaatsvindt vanwege de omstandigheid dat de deelnemer een doorlopend economisch belang houdt bij de door hem ingebrachte activa. De aan de activa verbonden risico"s en economische voordelen zijn weliswaar aan de joint venture als afzonderlijke entiteil overgedragen, maar effectief is alleen dat deel van de risico"s en economische voordelen aan derden overgedragen dat overeenkomt met het belang dat de andere deelnemers in de joint venture hebben. Proportionele winstbepaling is dus niet een eliminatie van in de enkelvoudige jaarrekening gerealiseerde winst, maar is een nader aspect van realisatie in de enkelvoudige jaarrekening zelf; er zou dus gesproken kunnen worden van proportionele realisatie.

Hoewel het IASC en de RJ niet aangeven welke redenen ten grondslag liggen aan proportionele winstbepaling, sluiten de gebruikte bewoordingen in zowel IAS 31.39 als RJ 214.809 goed aan bij de tweede invalshoek.

Bij deze benadering passen de volgende conclusies

1 Het beginsel van proportionele winstbepaling dient te worden toegepast in zowel de gecon- 
solideerde als in de enkelvoudige jaarrekening. In IAS 31 wordt deze conclusie niet expliciet getrokken; de RJ geeft in RJ 214.809 expliciet aan dat proportionele winstbepaling ook in de enkelvoudige jaarrekening dient plaats te vinden. Dit zou echter ook kunnen zijn ingegeven door de wens om, onder toepassing van de nettovermogenswaarde als waarderingsgrondslag voor deelnemingen, enkelvoudig en geconsolideerd vermogen en resultaat aan elkaar gelijk te doen zijn.

2 Proportionele winstbepaling zou, als aspect van realisatie, tevens van toepassing zijn op transacties met minderheidsdeelnemingen die tegen de nettovermogenswaarde worden verwerkt. Deze conclusie heeft het IASC getrokken in SIC 3, Elimination of Unrealised Profits and Losses on Transactions with Associates, dat voorschrijft dat unrealised profits and losses resulting from transactions between an investor (or its consolidated suhsidiaries) and associates should be eliminated to the extent of the investor's interest in the associate'. Men zou tegen deze 'eliminatie' kunnen inbrengen dat deze behandeling niet spiegelbeeldig is aan volledige eliminatie van winsten op transacties tussen groepsmaatschappijen, die ook vereist is indien het groepsbelang in één of beide groepsinaatschappijen minder bedraagt dan 100\%. Dit is echter een redenering die alleen past bij proportionele winstbepaling als element van consolidatie en is niet relevant indien men proportionele winstbepaling ziet als element van realisatie in de enkelvoudige jaarrekening.

3 Proportionele winstbepaling brengt tot uitdrukking dat een deel van de risico's en economische voordelen van de ingebrachte activa effectief nog bij de deelnemer berust. Als 'aftrekpost van realisatie' kan dit dan ook alleen betrekking hebben op het belang dat in de joint venture of minderheidsdeelneming wordt verkregen in ruil voor de inbreng van activa. Indien de deelnemer in de joint venture of minderheidsdeelneming daarnaast een bijbetaling ontvangt (in contanten of andere activa waarvan de realisatie onafhankelijk is van de toekomstige kasstromen van de joint venture-'boot'), is er mijns inziens geen reden om de winst ook op dit element proportioneel te bepalen. Dit deel kan dan ook volledig als gerealiseerd worden aangemerkt.

\subsection{Volledige verliesneming bij dunrame waardevermindering}

In vorenstaande paragrafen is steeds gesproken over proportionele winstbepaling, ervan uitgaande dat de fair value van de ingebrachte activa en passiva boven de daarvoor aangehouden boekwaarden ligt. Indien de fair value lager is dan de boekwaarden, wordt een verlies geconstateerd. In beginsel zou ook verlies slechts als gerealiseerd kunnen worden aangemerkt voor het deel dat correspondeert met het belang dat derden in de joint venture houden. Echter, een transactie tegen een fair value beneden de boekwaarde van de betrokken activa is een indicatie dat er sprake is van een waardevermindering. Volgens RJ 214.809 dient een dergelijk verlies dan ook volledig te worden genomen, tenzij er in geval van vaste activa sprake is van een tijdelijke waardevermindering. Alleen in dit laatste geval wordt een verlies niet volledig maar proportioneel genomen. Het IASC geeft hiervoor vergelijkbare aanwijzingen ${ }^{20}$.

\section{De bchandeling van goodwill}

In een joint venture kan een geheel van bedrijfsactiviteiten worden ingebracht waarvan de totale fair value meer (of minder) bedraagt dan de som van de fair values van de ingebrachte afzonderlijke activa en passiva. Bezien vanuit de joint venture valt dit meerdere (mindere) te beschouwen als gekochte goodwill (negatieve goodwill); bezien vanuit de inbrengende deelnemer kan dit bedrag tevens zelf gegenereerde goodwill bevatten. Ook een andere deelnemer in de joint venture kan goodwill inbrengen. Hierdoor ontstaat de situatie dat een deelnemer in een joint venture zelf gegenereerde goodwill inbrengt en via het belang in de joint venture goodwill verwerft afkomstig van de andere deelnemer(s). Er wordt als het ware goodwill uitgeruild.

Indien de inbreng in de joint venture tegen fair value wordt verwerkt (zie paragraaf 3 ), zal de omvang van de inbrengwinst mede afhangen van de waarde die wordt toegekend aan de ingebrachte goodwill. In beginsel hoeft dit niet bezwaarlijk te zijn, ware het niet dat een aan goodwill toe te kennen fair value vaak moeilijk objectief bepaalbaar is. Partijen zouden de aan goodwill toegekende bedragen - en daarmee de inbrengwinst - gelijkelijk kunnen verhogen of verlagen, zonder dat dit invloed heeft op de relatieve belangen van de deelnemers in 
de joint venture. Indien de fair value van de ingebrachte goodwill onvoldoende betrouwbaar kan worden bepaald, mede in relatie tot de door de andere deelnemers ingebrachte goodwill, valt te overwegen om op ingebrachte goodwill alleen (proportioneel) winst te nemen nadat de verworven goodwill daarop in mindering is gebracht.

\section{Voorbeeld 6}

De ondernemingen A en $B$ richten een 50-50 joint venture op $(C)$, waarin bepaalde activa en passiva worden ingebracht. Indien wordt verondersteld dat de ingebrachte activa en passiva ongelijksoortig zijn, zal de inbreng bij de deelnemers in beginsel tegen fair value worden verwerkt en zal winstneming aan de orde zijn. De relevante cijfers zijn opgenomen in tabel 1.

In dit voorbeeld wordt door A goodwill ingebracht voor in totaal 80 (waarvan 50 zelf gegenereerde goodwill), terwijl via het belang in de joint venture goodwill wordt verworven van $55(50 \%$ van $(80+30))$. De inbrengwinst bij A zou daarbij becijferd kunnen worden op 60 (50\% van (250130)). Deze inbrengwinst is voor 35 toe te rekenen aan de ingebrachte activa en passiva (exclusief goodwill) en voor 25 aan goodwill. Indien winst wordt genomen op ingebrachte goodwill nadat de verworven goodwill daarop in mindering is gebracht, valt een inbrengwinst te becijferen van 47.5 , waarvan 12,5 valt toe te rekenen aan ingebrachte goodwill, ofwel $50 \%$ van $(80-55)$.

Indien aan de zelfgegenereerde goodwill voor zowel $\mathrm{A}$ als $\mathrm{B}$ waarden worden toegekend van respectievelijk 150 en 130, zullen de relatieve belangen van $A$ en $B$ in de joint venture geen wijziging ondergaan. De inbrengwinst bij $A$ zou echter worden becijferd op $110(50 \%$ van (350$130)$ ), waarbij de stijging van dit bedrag (50) $50 \%$ betreft van het meerdere dat aan goodwill is toegekend. Indien winst wordt genomen op ingebrachte goodwill nadat de verworven good- will daarop in mindering is gebracht, komt de inbrengwinst ook hier uit op 47,5. Het aan goodwill toe te rekenen deel van de winst $(12,5)$ is daarbij berekend als $50 \%$ van (180-155). Onder deze methode wordt de berekening van de inbrengwinst derhalve niet beïnvloed door hogere of lagere aan goodwill toegekende bedragen.

Een bijzondere situatie kan ontstaan indien er in het verleden goodwill is betaald voor activiteiten die nu in de joint venture worden ingebracht en de inbrengende deelnemer de grondslag hanteert om betaalde goodwill rechtstreeks ten laste van het eigen vermogen te brengen. Winstneming op basis van de fair value van de inbreng (inclusief ingebrachte goodwill) lijkt alleen aanvaardbaar indien daarop de in het verleden ten laste van het vermogen gebrachte goodwill in mindering wordt gebracht. Dit klemt des te meer indien men bedenkt dat de via de joint venture verworven goodwill weer rechtstreeks ten laste van het vermogen wordt gebracht. Als alternatief zou wellicht verdedigbaar zijn om niet het gehele bedrag aan goodwill in mindering te brengen, maar een bedrag dat afneemt naarmate de inbreng verderaf ligt van het moment van aankoop van de nu ingebrachte activiteiten ${ }^{2 !}$.

\section{Voorbeeld 7}

Als voorbeeld 6, maar onderneming A brengt betaalde goodwill rechtstreeks ten laste van het eigen vermogen. In verband met de in joint venture $\mathrm{C}$ ingebrachte activiteiten is in het verleden 50 ten laste van het vermogen gebracht. Zonder correctie van de in het verleden afgeboekte goodwill bedraagt de inbrengwinst 75. De verworven goodwill van 55 zou rechtstreeks ten laste van het eigen vermogen van A worden gebracht. Correctie van het volledige bedrag van in het verleden afgeboekte goodwill resulteert in een inbrengwinst van $50(250-100=150$, verminderd met goodwill ad $50=100,(50 \%=50)$.

Tabel 1: Relevante cijfers bij voorbeeld 6

\begin{tabular}{|c|c|c|c|c|c|}
\hline & $\begin{array}{l}\text { Boekwaarde } \\
\text { deelnemer A }\end{array}$ & $\begin{array}{r}\text { Fair value } \\
\text { deelnemer A }\end{array}$ & $\begin{array}{l}\text { Boekwaarde } \\
\text { deelnemer } B\end{array}$ & $\begin{array}{l}\text { Fair ralue } \\
\text { deelnemer } B\end{array}$ & $\begin{array}{l}\text { Totale fair value } \\
\text { bij joint renture }\end{array}$ \\
\hline Activa/passiva & 100 & 170 & 180 & 220 & 390 \\
\hline Verworven goodwill & 30 & 30 & - & - & 110 \\
\hline Zelfgegenereerde goodwill & - & 50 & - & 30 & - \\
\hline Totale inbreng & 130 & 250 & 180 & 250 & 500 \\
\hline
\end{tabular}




\section{Samenvatting}

In deze bijdrage is ingegaan op enkele verslaggevingsaspecten die zich kunnen voordoen indien twee of meer deelnemers (een deel van) hun reeds bestaande activiteiten combineren door middel van een joint venture. Daarbij stond de vraag centraal of een deelnemer die activa en passiva inbrengt in een joint venture in verband daarmee winst kan verantwoorden en zo ja, hoe de omvang van deze winst kan worden bepaald.

Omtrent de vraag of bij inbreng van activa en passiva sprake is van realisatie, zijn twee benaderingen onderkend. Een eerste benadering gaat uit van het al dan niet gelijksoortig zijn van de door de verschillende deelnemers in een joint venture ingebrachte activa en passiva. Indien gelijksoortige activa en passiva worden ingebracht, wordt de joint venture aangemerkt als een voortzetting van bestaande activiteiten en wordt de som van de boekwaarden van de ingebrachte activa en passiva doorgeschoven naar de waardering van het belang in de joint venture. Indien daarentegen activa en passiva worden ingebracht die ongelijksoortig zijn van de door de andere deelnemer(s) ingebrachte activa en passiva, vindt verwerking van de transactie plaats tegen fair value en is winst- of verliesneming aan de orde. Deze benadering wordt onder meer gevolgd door het IASC, waarbij een zodanige invulling aan gelijksoortigheid is gegeven dat een inbreng in een joint venture vrijwel altijd zal moeten plaatsvinden tegen fair value. Onder een tweede benadering hangt winstneming af van de ontvangst van contanten of overige monetaire activa. Bij toepassing van deze benadering zal minder snel sprake zijn van winstneming.

Omtrent de bepaling van de omvang van de winst of het verlies bestaat in de regelgeving in hoofdlijnen duidelijkheid: indien winstneming aan de orde is, dient dat deel van het resultaat in de winst- en verliesrekening te worden verwerkt dat overeenstemt met het relatieve belang van andere deelnemers in de joint venture (proportionele winstbepaling). Een eventueel verlies dient volledig te worden genomen, tenzij er sprake is van een tijdelijke waardevermindering met betrekking tot vaste activa.

Het IASC en de RJ lijken het beginsel van proportionele winstbepaling te zien als een element van realisatie en niet als een element van consolidatie. Dit houdt in dat winstbepaling op proportionele basis dient plaats te vinden in zowel de geconsolideerde als de enkelvoudige jaarrekening. In lAS 31 wordt deze conclusie niet expliciet getrokken; de RJ stelt dit wel expliciet. De gedachte dat proportionele winstbepaling een element van realisatie is, brengt mee dat ook winsten op transacties met deelnemingen proportioneel worden bepaald. Deze conclusie is door het IASC inmiddels verwoord in SIC 3. De RJ heeft hieromtrent nog geen standpunt ingenomen.

\section{I T E R A T U U R}

APB Opinion nr. 16, Business Combinations.

APB Opinion nr. 29, Accounting for Nonmonetary Transactions. International Accounting Standards Committee, Framework for the Preparation and Presentation of Financial Statements.

International Accounting Standards Committee, IAS 16, Property, plant and equipment.

International Accounting Standards Committee, IAS 18 (revised 1993), Revenue.

International Accounting Standards Committee, IAS 31 (revised 1998), Financial Reporting of Interests in Joint Ventures.

IASC Standing Interpretations Committee, (1997), SIC 3, Elimination of Unrealised Profits and Losses on Transactions with Associates, november.

IASC Standing Interpretations Committee, (1998), SIC 13, Jointly Controlled Entities - Non Monetary Contributions by Venturers, november.

Eeftink, E., (1997), Uitkeerbare winst in groepsverhoudingen, Maandblad voor Accountancy en Bedriffeconomie, december

EITF Issue nr. 86-29, Nonmonetary Transactions: Magnitude of Boot and the Exceptions to the Use of Fair Value, February, 1987.

EITF Issue No. 87-29, Exchange of Real Estate Involving Boot, July, 1988.

EITF Issue No. 89-7, Exchange of Assets or Interest in a Subsidiary for a Noncontrolling Equity Interest in a New Entity. October 1989.

EITF Issue No. 98-3, Determining Whether a Transaction Is an Exchange of Similar Productive Assets or a Business Combination, March 1998.

Raad voor de Jaarverslaggeving, Richtliinen voor de jaarverslaggeving, Jaareditie 1998, hoofdstuk 214.

Turner, Lynn E. - Chief Accountant SEC, Letter to Timothy S. Lucas - Chairman Emerging Issues Task Force, Financial Accounting Standards Board, October 19, 1998. 


\section{N O T E N}

1 RJ 214.8 paragraaf 801.

2 IAS 31 (revised 1998) definieert joint control als the contractually agreed sharing of control over an economic activity'.

3 In beginsel kan de inbreng bestaan uit activa, passiva en niet in activa en passiva belichaamde bedrijfsactiviteiten inclusief goodwill. In dit artikel zal kortheidshalve veelal gesproken worden over de inbreng van activa.

4 in de structuur van regelgeving op het gebied van de financiële verslaggeving in de Verenigde Staten heeft de SEC als beurstoezichthouder een zeer belangrijke rol. Een 'verzoek' van de SEC aan de FASB of EITF is van dermate gewicht dat daaraan vrijwel zeker gehoor zal worden gegeven.

5 RJ 214.8 alinea 809; IAS 31 paragraaf 39.

6 RJ Richtlijnen (RJ 510.120), IAS 27 (paragraaf 17) en US accounting guidance (ARB 51 paragraaf 14) gaan bij consolidatie uit van volledige eliminatie van intercompany-winsten, aangezien dit aansluit op de onderliggende gedachte dat de geconsolideerde jaarrekening de financiële positie en resultaten van de groep weergeeft als ware het één enkele onderneming. Met andere woorden: het bedrag van de te elimineren intercompany-winst wordt niet beïnvloed door het bestaan van een minderheidsbelang. Zie echter tevens noot 19.

7 Het realisatiebeginsel is niet te verwarren met het matching-beginsel, dat aangeeft dat kosten dienen te worden toegerekend aan opbrengsten.

8 Het Stramien van de RJ is overigens een vertaling van 'Framework for the Preparation and Presentation of Financial Statements' van het IASC, waaraan de RJ enkele aantekeningen heeft toegevoegd die voor het onderwerp van dit artikel niet van belang zijn.

9 RJ Stramien voor de opstelling en vormgeving van de jaarrekeningen, paragraaf 92 . Met betrekking tot de verwerking van baten wordt door de RJ nog toegevoegd dat in de praktijk gehanteerde werkwijzen er vaak op zijn gericht om het verwerken van baten te beperken tot die posten waarvan de omvang betrouwbaar kan worden vastgesteld en die voldoende mate van 'zekerheid' bezitten.

10 Met betrekking tot de inbreng van activa in een joint venture is dit criterium expliciet opgenomen in IAS 31 paragraaf 39 en in RJ 214 alinea 809.

11 Deze voorbeelden zijn ontleend IAS 18, Revenue, paragraaf 16. Deze paragraaf bevat tevens een aantal andere voorbeelden waarin een verkopende onderneming in belangrijke mate het economisch risico blijft houden over de overgedragen activa, zodat geen opbrengst wordt verantwoord.

12 Men kan tevens stellen dat de risico's en economische voordelen verbonden aan de overgedragen activa slechts zijn overgedragen naar rato van het belang dat anderen in de joint venture houden. Dit aspect wordt echter separaat behandeld in paragraaf 4, zodat het hier verder buiten beschouwing blijft.

13 Als kostprijs van het ontvangen niet-monetaire actief wordt daarbij aangemerkt de fair value van het actief dat in de transactie aan de tegenpartij is overgedragen, of, indien dit beter bepaalbaar is, de fair value van het bij de transactie ontvangen niet-monetaire actief.

14 Zie bijvoorbeeld EITF 86-29 en EITF 89-7, alsmede de brief van de Chief Accountant van de SEC aan de voorzitter van de EITF d.d. 19 oktober 1998.

15 APB 29, Accounting for Nonmonetary Transactions, paragraaf 22, bespreekt de behandeling van 'boot' die onderdeel uitmaakt van een overigens niet-monetaire transactie die niet tegen fair value wordt verwerkt (onder meer in het geval van ruilen van gelijksoortige activa). Volgens APB 29 heeft 'boot' tot gevolg dat de transactie wordt gesplitst in een monetair en een niet-monetair deel en dient op het monetaire deel winstneming plaats te vinden op pro rata basis. In het later verschenen EITF 86-29 is deze pro rata basis van winstneming beperkt tot die situaties waarin 'boot' minder bedraagt dan $25 \%$ van de fair value van de transactie.

16 EITF Issue No. 86-29. Overigens heeft de EITF in Issue No. 87-29 (Exchange of Real Estate involving Boot) bepaald dat bij transacties waar gelijksoortig onroerend goed wordt uitgewisseld en tevens een bijbetaling plaatsvindt, ook bij een percentage van 'boot' boven de $25 \%$ op pro rata basis winst wordt verantwoord. Hiermee is EITF $86-29$ voor bepaalde soorten onroerendgoedtransacties aangepast aan de bepalingen van FAS 66 (Accounting for Sales of Real Estate).

17 Uit zowel IAS 31 als uit RJ 214.8 kan impliciet worden afgeleid dat het beginsel van proportionele winstbepaling van toepassing is op alle joint ventures die aan de definitie van een joint venture voldoen: of de joint venture proportioneel wordt geconsolideerd of tegen de nettovermogenswaarde wordt opgenomen is voor dit beginsel dus niet relevant.

18 Zie Eeftink, (1997).

19 Indien het groepsbelang in één of beide groepsmaatschappijen minder bedraagt dan 100\%, komt de vraag op of een deel van de eliminatie moet worden toegerekend aan het minderheidsbelang of dat het gehele bedrag ten laste van de groepswinst (voor minderheden) moet worden gebracht. Hieromtrent bestaat geen eensluidende opvatting. In het Engelse FRS 2 (Accounting for subsidiary undertakings) paragraaf 39 is opgenomen dat toerekening aan aandeelhouders plaatsvindt op basis van de belangen die in de verkopende maatschappij worden gehouden. Bij een 'downstream'-transactie (bijvoorbeeld: 100\%-maatschappij verkoopt aan 70\%maatschappij) wordt de gehele eliminatie toegerekend aan de groepswinst. Bij een 'upstream'-transactie (bijvoorbeeld: $70 \%$ maatschappij verkoopt aan 100\%-maatschappij) wordt $70 \%$ van de eliminatie verwerkt in de groepswinst en $30 \%$ in het minderheidsbelang. 


\section{Zie IAS 31 paragrafen 39 en 40 en SIC 3.}

21 Zie in dit verband RJ 214 alinea 234. Daarin wordt aangegeven dat er bij verkoop van een deelneming aanleiding kan zijn om bij de bepaling van het verkoopresultaat rekening te houden met in het verleden van het vermogen afgeboekte goodwill. Een staffel geeft vervolgens aan welk percentage van de afgeboekte goodwill bij de bepaling van het verkoopresultaat ten minste dient te worden teruggenomen (bij verkoop binnen een jaar het gehele bedrag, bij verkoop binnen twee jaar ten minste $80 \%$, bij verkoop binnen drie jaar ten minste $60 \%$, et cetera).

\section{BESTELBON}

De acht bijdragen die sinds mei 1997 zijn verschenen over de rol van de accountant zijn gebundeld verkrijgbaar onder de titel 'De rol van de accountant, nu en in de toekomst'.

$\cup$ kunt dit boek bestellen door deze bon* ingevuld te sturen of te faxen naar:
Elsevier bedrifsinformatie $b v$

Postbus 16500

2500 BM 's-Gravenhage

Fax: 070 - 4415999

Telefonisch bestellen kan ook: 070 - 4415555.

JA, ik bestel ex. van 'De rol van de accountant, nu en in de toekomst' a $f 32,50^{* *}$.

Naam $m / v$

Werkzaam bij

Postadres

Postcode/plaats

Afleveradres

Postcode/plaats

* Indien u dit tijdschrift niet wilt beschadigen volstaat een kopie. ** Inclusief btw, exclusief administratie- en verzendkosten. 